\title{
Effect of pre-harvest practices on physical and colorimetric characteristics of date fruit (cv. (Aziza Bouzid') in Figuig oasis
}

\author{
Kawtar Jdaini ${ }^{1 *}$, Fouzia Alla ${ }^{1}$, Kamal Guerrouj ${ }^{2}$, and Mohamed Aziz Elhoumaizi ${ }^{1}$ \\ ${ }^{1}$ Laboratory for Agricultural Productions Improvement, Biotechnology and Environment (LAPABE), \\ Faculty of Sciences, University Mohammed First, BP-717, 60000 Oujda, Morocco \\ ${ }^{2}$ Higher Institute of Health Professions and Nursing Skills, 60000 Oujda, Morocco
}

\begin{abstract}
Dates represent a very important energy source that contains a wide range of functional, nutritional, bioactive, and aromatic components. Dates characteristics have been widely studied but none has been conducted on the pre-harvest factors responsible for the quality variation. The aim of this study is to evaluate the effect of pre-harvest practices on physical and colorimetric characteristics. The analyses were conducted on twelve samples of 'Aziza Bouzid' cultivar and collected at Tmar stage from Figuig oasis. Results obtained for physical parameters show a significant variation between different samples. Weight of 'Aziza Bouzid' varied from $5.44 \mathrm{~g}$ to $9.04 \mathrm{~g}$. Geometric mean diameter and Porosity varied from $13.08 \mathrm{~mm}$ to $17.01 \mathrm{~mm}$ and $31.88 \%$ to $42.3 \%$ respectively for 'Aziza Bouzid'. Highest Chroma and hue values registered for 'Aziza Bouzid' were 38.14 and 83.22 and the lowest were 21.1 and 67.15. This study contributes to develop good agricultural practices, help improve the quality and increase the quantity of Moroccan date production.
\end{abstract}

\section{Introduction}

Date palm (Phoenix dactylifera L.) is one of the oldest fruit trees grown in arid regions of Arabian Peninsula, North Africa and the Middle East [1]. It has been cultivated for ecological, economical and social purposes. Dates fruit are considered as a good source of sugars (fructose, glucose and sucrose) and fibers, important vitamins and minerals [2].

Morocco production areas were estimated to 50.000 ha concentrated mainly in the oases of Draâ, Ziz, Tata, Tiznit, Guelmim and Figuig [3-4]. Dates production in the country has reached an average of 129,562 tons in 2017 [5] composed of more than 220 cultivars including high proportion of Khalts (originated from seed) and other high value cultivars such as 'Boufeggous', 'Medjool', 'Bouskri', and 'Aziza bouzid' [6].

Total date production in the Figuig oasis for the 2012-2013 campaign is estimated at 3384 tones. It is dominated by the Assiane cultivar, followed by Boufeggous and Khalts. However 'Aziza Bouzid', which is the flagship profile of this region is only $39 \mathrm{~T}$ and therefore only represents $3.2 \%$ [7].

\footnotetext{
*Corresponding author: jdaini91@gmail.com
} 
Fruits quality may be affected by different factors, they are classified in three groups; preharvest, harvest and post-harvest processes .Pre-harvest including firstly Climatic condition like temperature light rains winds and humidity [8].Secondly Tree condition as variety tree age, fruit positioning [9] and finally Cultural practices (Irrigation, use of fertilizers etc). Harvest factors relating at maturity at harvest and method and harvest time [8]. As for postharvest factors, Washing, Pre-cooling, Grading, Packaging, Transportation, Cold storage, Marketing can also affect fruit quality by modifying physiology, chemical composition, and morphology of fruits [9].

Knowledge of physical properties of agricultural produce and the parameters, which affected these characteristics, is a critical aspect to formulate the proper design standards of harvesting, handling, processing, and storing equipment [10]. The mass, size and shape are important for sorting, sizing and various separation. Density, surface areas and porosity of fruit solids must be known for accurate modelling of heat and mass transfer during drying and Colling [11].

Numerous studies have been carried out on the physical parameters of dates fruits. But none have been studied for the design, development of machinery and equipment for handling, processing, transporting and storing Moroccan cultivars. [12] Reported that the length, width and thickness of 'Zahidi' cultivars were $33.65 \mathrm{~mm}, 22.12 \mathrm{~mm}, 20.02 \mathrm{~mm}$ respectively. GMD and AMD were 23.51-25.96mm and 24.29-26.59mm, respectively. The Sphericity value ranged from 0.73 to 0.737 . [13] Investigated the physical parameters of dates fruit, and discovered that the values of axial dimensions and weight of cultivar Medjool were significantly higher than those of variety 'Khadrawy'. According to [14] the linear measurements of cultivar 'Mazafati' ranged from 32.10 to $43.50 \mathrm{~mm}$ in length, 20.50 to $28.20 \mathrm{~mm}$ in width and the average weight was $8.39 \mathrm{~g}$. The density of the fruits was 0.82 $\mathrm{g} / \mathrm{cm} 3$ and the density of the pitted fruits was $1.25 \mathrm{~g} / \mathrm{cm} 3$, respectively. Bulk density and porosity were $0.44 \mathrm{~g} / \mathrm{cm} 3$ and $44.90 \%$. GMD, Sphericity and area were calculated to be $27.87 \mathrm{~mm}, 0.73 \mathrm{~mm}^{2}$ and $2446.70 \mathrm{~mm}^{2}$ correspondingly.

The effect of pre-harvest practices on the physical characteristics of dates has been discussed by some authors. [15] found out that thinning the center of the bunch by removing $15-30 \%$ of the total number of sprigs improved various physical and chemical aspects of the fruits of the "Khadrawi" date palm. According to research by [16], Bagging fruit bunches increased the weight of date bunches, accelerated ripening, and improved fruit quality compared to unbagged bunches. [17] found that irrigation systems can also alter the physical qualities of fruits.

The aims of this study are to determine physical properties for 'Aziza Bouzid' cultivar and to evaluate interaction between pre-harvest factors and these properties .To facilitate the design of some machines for its processing.

\section{Materiel and methods}

\subsection{Study area}

Figuig oasis situated in southeast at the Oriental region of Morocco (Latitude $32^{\circ} 18 \mathrm{~N}$, longitude $1^{\circ} 15 \mathrm{~W}$ ), at $900 \mathrm{~m}$ altitude. It's characterised by arid climate, in which the annual average temperature of the region is $20^{\circ} \mathrm{C}$. This average covers large seasonal variations and daily amplitudes. Daily amplitudes range from $3{ }^{\circ} \mathrm{C}$ to $16{ }^{\circ} \mathrm{C}$ in winter and $24{ }^{\circ} \mathrm{C}$ to 42 ${ }^{\circ} \mathrm{C}$ in summer (DPA, 2009). As for rainfall, annual average does not exceed $125 \mathrm{~mm}$ (Tag, 2003). 
Fig. 1.Figuig oasis (sources: google earth 2009. Traitement: ArcGis 10 (C. Production: G. Janty, 2014; UMR Ladyss, University Paris Diderot)

\subsection{Fruit Materiel:}

Fruit material is composed of the most appreciated cultivar in the oasis of Figuig. Twelve samples of 'Aziza Bouzid' cultivar were collected at Tmar stage from twelve plots chosen randomly in Figuig oasis. Each sample was carried out according to a factorial schemas $20 \times 5 \times 1$ (dates $\times$ trees $\times$ plot). Date palm trees used in this study were identified as homogeneous (same age, height and intact). Dates samples were transported in isotherm bags to the laboratory, then stored at $-20{ }^{\circ} \mathrm{C}$ until further analysis.

Table 1. Names and code plots

\begin{tabular}{|c|c|c|}
\hline & Areas denomination & Code \\
\hline \multirow{12}{*}{ 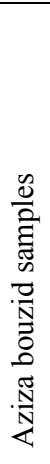 } & Aarja & Arj \\
\hline & Cooperative Aziza & Cop.A \\
\hline & Znaga 1 & Zng.1 \\
\hline & Znaga 2 & Zng.2 \\
\hline & Znaga 3 & Zng.3 \\
\hline & Znaga4 & Zng.4 \\
\hline & Hamam Tahtani & $\mathrm{Ht}$ \\
\hline & Laabidate & $\mathrm{Lb}$ \\
\hline & Oulad lmaiz 1 & OM.1 \\
\hline & Oulad lmaiz 2 & OM.2 \\
\hline & Oulad Slimane & Os \\
\hline & Loudaghir & $\mathrm{Lg}$ \\
\hline
\end{tabular}

\subsection{Field investigation}

Field investigation on each plot was reposed mainly on tree characteristics (Age and height of tree), and also on cultural practices used such as (limitation, thinning and bagging of bunches, irrigation and fertilization technics, method of pollination, presence or not of intercropping) 


\subsection{Physical analysis}

\subsubsection{Size and weight measurements}

Dimensions measurements were realized on 100 fruits per samples. Width (W), Length (L), and thickness $(\mathrm{T})$ are carried out using a digital caliper. Dates, seed, and pulp weight (Wt) were determined by weighing samples with precision balance (RADWAG PS 360.R2). The percentage of seed and pulp on the whole fruit was calculated using formulas (1) and (2) respectively;

$$
\begin{aligned}
\text { Ratio } P / D(\%) & =(P . W t / F . W t) * 100 \\
\text { Ratio } S / D(\%) & =(S . W t / F . W t) * 100
\end{aligned}
$$

\subsubsection{Geometric and arithmetic mean diameter, Sphericity, aspect ratio and surface area}

Geometric and arithmetic mean diameter (GMD, AMD) obtained from the measured geometric dimensions of Width (W), length (L) and thickness (T) as (3) and (4) formulas [17-18].

$$
\begin{gathered}
G M D=(L W T)^{I / 3} \\
A M D=(L+W+T) / 3
\end{gathered}
$$

Sphericity expresses solid object shape relative to that sphere of same volume [18]. It is a relevant property to calculate fluid flow, heat and mass transfer. Sphericity was calculated by using the equations (5)

$$
\Phi=G M D / L
$$

Surface area is an important physical parameter that is related to size and shape. It is found by using relation reported by [19];

$$
S=\pi * G M D
$$

Aspect ratio of fruit indicates its tendency to be an oblong shape during handling and processing. It is calculate by equation (7) described by [19]

$$
\mathrm{R}=\mathrm{W} / \mathrm{L} \times 100
$$

\subsubsection{Bulk and true density and porosity}

The true density $(\rho T)$ is determined by the water displacement method [20] which the volume of water displaced was estimated by immersing the weighed quantity of fruits in water. Whereas Bulk density $\rho b$ is the mass (M) of a group of individual fruit occupied a box of known volume (V) [21]. Fruits were poured into a standard container without compaction and afterward the content was weighed. The bulk density is calculated as the ratio of fruits mass only to container volume.

Bulk and true density respectively were expressed on $\left(\mathrm{g} \mathrm{cm}^{-3}\right)$ and calculated as (8) equation 
Porosity is the percentage of air between the fruits compared to a unit volume of fruit [21]; it was calculated using equation (9)

$$
P=\left(\left(\rho_{T}-\rho_{b}\right) / \rho_{T}\right) * 100
$$

\subsection{Color measurement}

Fruits color properties were measured using a Chroma Meter CR 400 and were expressed according to the CIELAB color space system defined by International Commission on Illumination (CIE) in 1976. Coordinates $\mathrm{L}^{*}$ define to lightness $\mathrm{a}^{*}$ correspond a red and green ratio and $\mathrm{b}^{*}$ indicate ratio yellow and blue. The chroma $\mathrm{C}^{*}$ and Hue $\mathrm{H}^{*}$ were defined according to the mathematical functions $(10,11)$.

$$
C^{*}=\sqrt{ }\left(a^{* 2}+b^{* 2}\right)(10) \quad ; \quad H^{*}=\operatorname{tg}^{-1}\left(b^{*} / a^{*}\right)
$$

\subsection{Statistical analysis}

Data analysis was performed using SPSS Statistics 19.0 package (SPSS Inc., Chicago, USA). One-way analysis of variance (ANOVA) and Duncan's multiple-range test were applied to determine significant differences between means and to separate groups of means with a probability $\mathrm{p} \leq 0.05$ according to their physical and colorimetric characteristics. Values were expressed as an average of four determinations \pm standard deviation. Principal component analysis (PCA) was performed on the physical data set in order to verify whether it was possible to differentiate the samples according to their soil condition and pre-harvest practices and to obtain information of variable that influence physical parameters of 'Aziza Bouzid' and Assiane cultivars

\section{Results and discussion}

\subsection{Physical analysis}

Size measurements (width, length, weigh and thickness) are presented in Table2. Measurements of size revealed a significant variation between different samples of 'Aziza Bouzid' cultivar collected from different plot in Figuig oasis, except percentage of pulp per date that show no significant difference. For length and width, Hamam Tahtani sample has the largest size with a length of $36.77 \mathrm{~mm}$ and a width of $19.69 \mathrm{~mm}$. The smaller length was recorded for Znaga 1 (Zng.1) (length=29.60 mm) and smaller width for Loudaghir (width = 16.77). Weight was fluctuating between $5.92 \mathrm{~g}$ for Loudaghir $(\mathrm{Lg})$ and $17.52 \mathrm{~g}$ for Hamam Tahtani (Ht). Weight of pulp varied between $8.20 \mathrm{~g}$ for Hamam Tahtani $(\mathrm{Ht})$ and $4.71 \mathrm{~g}$ for Loudaghir $(\mathrm{Lg})$. Percentage of seed per date is ranging between $13.52 \%$ for 'Aziza Bouzid' of Zng.4 to $20.72 \%$ Lg. 
Table 2. Size measurements of date fruit (cv. 'Aziza Bouzid')

\begin{tabular}{|c|c|c|c|c|c|c|c|c|c|c|}
\hline & \multicolumn{3}{|c|}{ Fruits } & \multicolumn{3}{|c|}{ Seeds } & \multicolumn{2}{|c|}{ Pulps } & \multirow{2}{*}{$\begin{array}{c}\text { Ratio } \\
\text { Seed/Date }\end{array}$} & \multirow{2}{*}{$\begin{array}{c}\text { Ratio } \\
\text { Pulpe/Date }\end{array}$} \\
\hline & $\begin{array}{c}\text { Length } \\
(\mathrm{mm})\end{array}$ & $\begin{array}{l}\text { Width } \\
(\mathrm{mm})\end{array}$ & $\begin{array}{c}\text { Weight } \\
\text { (g) }\end{array}$ & $\begin{array}{l}\text { Length } \\
(\mathrm{mm})\end{array}$ & $\begin{array}{l}\text { Width } \\
(\mathrm{mm})\end{array}$ & $\begin{array}{c}\text { Weight } \\
\text { (g) }\end{array}$ & $\begin{array}{c}\text { Weight } \\
\text { (g) }\end{array}$ & $\begin{array}{c}\begin{array}{c}\text { Thickness } \\
(\mathrm{mm})\end{array} \\
\end{array}$ & & \\
\hline Arj & $33.79 \pm 0.63^{\mathrm{dc}}$ & $18.95 \pm 0.54^{\circ}$ & $8.37 \pm 0.47^{1}$ & $23.55 \pm 1.20^{\mathrm{ef}}$ & $9.08 \pm 0.56^{\mathrm{bc}}$ & $1.18 \pm 0.2^{\mathrm{c}}$ & $7.20 \pm 0.41^{g}$ & $3.85 \pm 0.18^{\mathrm{a}}$ & $14.96 \pm 1.93^{\text {abc }}$ & $85.67 \pm 2.29^{\mathrm{a}}$ \\
\hline Cop.A & $34.58 \pm 1.15^{\mathrm{e}}$ & $18.56 \pm 0.62^{\mathrm{de}}$ & $7.24 \pm 0.56 \mathrm{~d}^{\mathrm{c}}$ & $23.12 \pm 0.94^{\mathrm{de}}$ & $8.46 \pm 0.36^{\mathrm{a}}$ & $1.01 \pm 0.11^{\mathrm{ab}}$ & $6.23 \pm 0.50^{\mathrm{ct}}$ & $4.08 \pm 0.50^{\mathrm{a}}$ & $13.90 \pm 1.41^{\mathrm{a}}$ & $86.10 \pm 1.41^{\mathrm{a}}$ \\
\hline Zng.2 & $34.59 \pm 0.89^{\mathrm{e}}$ & $18.57 \pm 0.34^{\mathrm{de}}$ & $7.07 \pm 0.39^{\text {cde }}$ & $22.75 \pm 0.71^{\text {cde }}$ & $8.82 \pm 0.19^{\mathrm{abc}}$ & $1.10 \pm 0.06^{\mathrm{abc}}$ & $5.97 \pm 0.33^{\text {def }}$ & $3.80 \pm 0.34^{\mathrm{a}}$ & $15.63 \pm 0.63^{\mathrm{abc}}$ & $84.37 \pm 0.63^{\mathrm{a}}$ \\
\hline Zng.3 & $30.13 \pm 1.09^{\mathrm{a}}$ & $17.25 \pm 0.71^{\mathrm{ab}}$ & $6.44 \pm 0.38^{\text {abc }}$ & $21.10 \pm 1.15^{\text {ab }}$ & $8.94 \pm 0.35$ & $1.15 \pm 0.12^{\mathrm{bc}}$ & $5.29 \pm 0.38^{\text {abcd }}$ & $3.69 \pm 0.25^{\mathrm{a}}$ & $18.21 \pm 1.75^{\mathrm{d}}$ & $81.79 \pm 1.75^{\mathrm{a}}$ \\
\hline Zng.4 & $31.10 \pm 1.02^{\mathrm{abc}}$ & $17.99 \pm 0.54^{\mathrm{bed}}$ & $7.59 \pm 0.73^{\text {ef }}$ & $20.73 \pm 1.16^{\text {ab }}$ & $8.74 \pm 0.20^{\text {abc }}$ & $1.00 \pm 0.06^{\mathrm{ab}}$ & $6.59 \pm 0.73^{\text {fg }}$ & $3.96 \pm 0.43^{\mathrm{a}}$ & $13.5 \pm 1.68^{\mathrm{a}}$ & $86.48 \pm 1.68^{\mathrm{a}}$ \\
\hline $\mathrm{Ht}$ & $36.77 \pm 0.88^{t}$ & $19.69 \pm 0.37^{\mathrm{t}}$ & $9.58 \pm 0.43^{\mathrm{g}}$ & $24.66 \pm 0.52^{\mathrm{T}}$ & $9.41 \pm 0.19^{\text {cd }}$ & $1.38 \pm 0.07^{\mathrm{d}}$ & $8.20 \pm 0.42^{\mathrm{h}}$ & $4.54 \pm 0.37^{\mathrm{ab}}$ & $14.59 \pm 0.64^{\mathrm{abc}}$ & $85.41 \pm 0.64^{\mathrm{a}}$ \\
\hline OM.2 & $30.59 \pm 0.74^{\mathrm{ab}}$ & $17.55 \pm 0.38^{\mathrm{bc}}$ & $6.09 \pm 0.33^{\text {ab }}$ & $20.66 \pm 0.52^{\mathrm{ab}}$ & $8.77 \pm 0.41^{\text {abc }}$ & $1.00 \pm 0.07^{\mathrm{ab}}$ & $5.09 \pm 0.34^{\text {abc }}$ & $3.75 \pm 0.35^{\mathrm{a}}$ & $16.49 \pm 1.62^{\mathrm{bed}}$ & $83.51 \pm 1.62^{\mathrm{a}}$ \\
\hline Os & $31.81 \pm 0.96^{\mathrm{abc}}$ & $17.94 \pm 0.42^{\mathrm{bed}}$ & $6.77 \pm 0.33^{\text {bcd }}$ & $21.46 \pm 0.73^{\text {abc }}$ & $8.81 \pm 0.25^{\text {abc }}$ & $0.98 \pm 0.11^{\mathrm{a}}$ & $5.80 \pm 0.24^{\mathrm{cde}}$ & $4.08 \pm 0.49^{\mathrm{b}}$ & $14.35 \pm 1.31^{\mathrm{ab}}$ & $85.65 \pm 1.31^{\mathrm{a}}$ \\
\hline $\mathrm{Lg}$ & $30.25 \pm 1.42^{\mathrm{a}}$ & $16.77 \pm 0.55^{\mathrm{a}}$ & $5.92 \pm 0.63^{\mathrm{a}}$ & $22.02 \pm 0.68^{\text {bed }}$ & $8.95 \pm 0.47^{\mathrm{bc}}$ & $1.21 \pm 0.15^{\mathrm{c}}$ & $4.71 \pm 0.63^{\mathrm{a}}$ & $3.98 \pm 0.84^{\mathrm{a}}$ & $20.72 \pm 3.15^{\mathrm{e}}$ & $79.28 \pm 3.15^{\mathrm{a}}$ \\
\hline
\end{tabular}

Table 3. Some physical properties of date fruit (cv. 'Aziza Bouzid')

\begin{tabular}{|c|c|c|c|c|c|c|c|c|}
\hline & AMD & GMD & $\mathbf{R}$ & Фs & $\mathbf{S}$ & Bulk density & True density & Porosity \\
\hline Arj & $20.37 \pm 1.50^{\text {de }}$ & $14.07 \pm 0.74^{\text {abce }}$ & $52.46 \pm 4.06^{\mathrm{abc}}$ & $0.39 \pm 0.05^{\text {abcd }}$ & $655.66 \pm 67.08^{\mathrm{ab}}$ & $0.64 \pm 0.03^{\text {def }}$ & $1.01 \pm 0.06^{\mathrm{a}}$ & $36.60 \pm 3.68^{\mathrm{abc}}$ \\
\hline Cop.A & $19.07 \pm 0.88^{\mathrm{e}}$ & $14.58 \pm 1.42^{\mathrm{bc}}$ & $53.72 \pm 2.11^{\mathrm{a}}$ & $0.42 \pm 0.04^{\mathrm{ab}}$ & $677.34 \pm 137.87^{\mathrm{ab}}$ & $0.65 \pm 0.05^{\mathrm{cd}}$ & $0.95 \pm 0.06^{\mathrm{a}}$ & $31.22 \pm 6.72^{\mathrm{a}}$ \\
\hline Zng.1 & $17.38 \pm 0.69^{\mathrm{ab}}$ & $14.31 \pm 1.14^{\mathrm{abc}}$ & $60.87 \pm 5.19^{\mathrm{d}}$ & $0.48 \pm 0.05^{\mathrm{e}}$ & $649.74 \pm 105.67^{\mathrm{ab}}$ & $0.66 \pm 0.02^{\text {def }}$ & $1.07 \pm 0.09^{\mathrm{a}}$ & $37.90 \pm 6.19^{\mathrm{bc}}$ \\
\hline Zng.2 & $18.99 \pm 0.71^{\text {de }}$ & $14.29 \pm 1.08^{\mathrm{abc}}$ & $53.94 \pm 3.78^{\mathrm{a}}$ & $0.42 \pm 0.04^{\mathrm{ab}}$ & $647.25 \pm 97.73^{\mathrm{ab}}$ & $0.66 \pm 0.02^{\text {det }}$ & $0.96 \pm 0.03^{\mathrm{a}}$ & $30.87 \pm 3.57^{\mathrm{a}}$ \\
\hline Zng. 3 & $17.02 \pm 0.91^{\mathrm{a}}$ & $13.20 \pm 0.63^{\mathrm{a}}$ & $57.47 \pm 3.85^{\mathrm{bc}}$ & $0.44 \pm 0.02^{\text {abced }}$ & $549.17 \pm 53.45^{\mathrm{a}}$ & $0.68 \pm 0.03^{\text {det }}$ & $1.10 \pm 0.11^{\mathrm{a}}$ & $37.56 \pm 7.16^{\mathrm{bc}}$ \\
\hline Zng.4 & $17.68 \pm 0.55^{\mathrm{abc}}$ & $14.48 \pm 2.84^{\text {abc }}$ & $57.93 \pm 2.18^{\mathrm{c}}$ & $0.47 \pm 0.05^{\mathrm{cdc}}$ & $668.90 \pm 151.76^{\mathrm{ab}}$ & $0.65 \pm 0.04^{\text {cde }}$ & $1.10 \pm 0.07^{\mathrm{a}}$ & $40.37 \pm 5.18^{\mathrm{c}}$ \\
\hline $\mathrm{Ht}$ & $20.33 \pm 1.35^{\mathrm{t}}$ & $16.44 \pm 0.79^{\mathrm{d}}$ & $56.36 \pm 3.21^{\text {abc }}$ & $0.45 \pm 0.05^{\text {bde }}$ & $852.81 \pm 82.82^{\mathrm{c}}$ & $0.68 \pm 0.04^{\mathrm{t}}$ & $1.17 \pm 1.33^{b}$ & $41.88 \pm 3.77^{\circ}$ \\
\hline $\mathrm{Lb}$ & $18.06 \pm 1.66^{\text {bcd }}$ & $14.11 \pm 2.71^{\text {abc }}$ & $54.99 \pm 3.69^{\mathrm{abc}}$ & $0.43 \pm 0.04^{\text {abc }}$ & $650.71 \pm 240.39^{\mathrm{ab}}$ & $0.58 \pm 0.02^{\mathrm{a}}$ & $0.96 \pm 0.05^{\mathrm{a}}$ & $38.98 \pm 4.55^{\circ}$ \\
\hline OM.1 & $17.30 \pm 0.54^{\mathrm{ab}}$ & $13.39 \pm 0.83^{\mathrm{ab}}$ & $54.47 \pm 2.25^{\mathrm{bc}}$ & $0.44 \pm 0.02^{\text {abced }}$ & $566.86 \pm 69.91^{\mathrm{a}}$ & $0.68 \pm 0.03^{\mathrm{er}}$ & $1.06 \pm 0.05^{\mathrm{a}}$ & $35.52 \pm 3.17^{\text {abc }}$ \\
\hline OM.2 & $17.77 \pm 0.82^{\mathrm{abc}}$ & $13.30 \pm 0.72^{\mathrm{ab}}$ & $54.62 \pm 2.42^{\mathrm{ab}}$ & $0.41 \pm 0.02^{\mathrm{a}}$ & $558.25 \pm 61.25 \mathrm{a}$ & $0.61 \pm 0.03^{\text {ab }}$ & $1.04 \pm 0.11^{\mathrm{a}}$ & $40.99 \pm 6.44^{\circ}$ \\
\hline Os & $18.61 \pm 1.33^{\text {cde }}$ & $14.81 \pm 1.77^{\mathrm{c}}$ & $56.55 \pm 3.03^{\text {abc }}$ & $0.47 \pm 0.06^{\mathrm{de}}$ & $727.33 \pm 209.99^{b}$ & $0.63 \pm 0.04^{\mathrm{bc}}$ & $1.06 \pm 0.09^{\mathrm{a}}$ & $40.44 \pm 3.87^{\mathrm{c}}$ \\
\hline $\mathrm{Lg}$ & $17.00 \pm 0.63^{\mathrm{a}}$ & $13.35 \pm 0.89^{\mathrm{ab}}$ & $55.57 \pm 2.43^{\text {abc }}$ & $0.44 \pm 0.01^{\text {abcd }}$ & $562.82 \pm 74.44^{\mathrm{a}}$ & $0.69 \pm 0.03^{\mathrm{I}}$ & $1.02 \pm 0.07^{\mathrm{a}}$ & $31.88 \pm 6.90^{\mathrm{ab}}$ \\
\hline
\end{tabular}

Values are average $(\mathrm{n}=100) \pm$ standard deviation. Different litters (a-g) show significant differences in the same row

AMD: Arithmetic mean diameter, GMD: geometric mean diameter, R: Aspect ratio, Фs: Sphericity, S: Surface area 
Pulp thickness was ranging between $3.58 \mathrm{~mm}$ for Loudaghir (Lg), Oulad Lmaiz 2 (OM.2) and 4.59g, 4.54g respectively for Hamam Tahtani (Ht) and Znaga 1(Zng.1). Percentage of seed per date is ranging between 13.52\% for 'Aziza bouzid' of Zng.4 to $20.72 \%$ of $\mathrm{Lg}$. These findings corroborate with [22] results for Tunisian cultivar has indicate an important differences between dates of different varieties, but also within same varieties. [23] Also revealed that morphological analysis of cultivar grown in Saudi showed a high level of diversity in length-width ratio, color, shape of the fruit, fruit-base and in the percentage of area covered by the fruit cap. Great variability was also reported between Pakistani cultivars by [24].

Geometric mean diameter, Sphericity, Surface area, Bulk and true density (table 3) show a significant difference $(\mathrm{p}<0.05)$. Geometric mean diameter GMD of Znaga 3 (Zng.3) sample had the lowest value $(13.20 \mathrm{~mm})$ whereas Ht had the highest $(20.72 \mathrm{~mm})$. Sphericity varied from $38.70 \%$ for Arj to $48.5 \%$ for Znaga 1 (Zng.1). The surface area varied from $852,81 \mathrm{~mm}^{2}$ Hamam Tahtani (Ht) to 549, $17 \mathrm{~mm} 2$ Znaga 3 (Zng.3). Lowest data of bulk density was $0.58 \mathrm{~g} \mathrm{~cm}-3$ for $\mathrm{Lb}$ and the highest was 0.69 for $\mathrm{Lg}$. The physical parameters variability was reported also by [15-25], for Mazafati and 'Dairi' cultivars from Tehran.

The study revealed an important variability from different 'Aziza Bouzid' samples. Highest quality of dates samples was from the Hamam Tahtani (Ht), Aarja (Arj) and cooperative Aziz (Cop.A) plot may be due to the good practices used. The lowest quality registered for Oulad lmaiz and Loudaghir $(\mathrm{Lg})$ owed to the use of traditional cultural practices. The investigation revealed that Hamam Tahtani, Aarja and cooperative Aziza (Good 'Aziza Bouzid' fruits quality) are the recent date palm plantations that adapt good cultural practices, such as respect of regular plantation and use of drips irrigation, use organic and mineral fertilizer. In addition to developed pre-harvest practices as cleaning trees and limitation, thinning, protecting fruit bunches .However, Oulad lmaiz and Loudaghir ( low 'Aziza Bouzid') fruits quality plots belong to the ancient palm grove which is characterized by irregular planting, heterogeneous varietal profile, and use of ancestral practices. In the fact, according to [26], thinning of bunches induces to increase in fruit volume, weight, diameter, and length; along with seed and flesh weight in the 'Succary' cultivar. An irrigation system can also affect the physical properties of fruits; Findings given from the North African and Middle East countries marked that irrigation systems have an important influence on dates quality [17].

Variation interval of physical parameters raised in this study for 'Aziza Bouzid' allows to elaborate standards for machines designs. Dimensions are important physical parameters for drying, storing and are also useful to determinate the shape of the fruits. Arithmetic mean diameter and geometric mean diameter values are used to design of separating, harvesting, sizing and grinding machine. Determined Sphericity values serving to concept handling equipment of fruits. The porosity of dates fruits is important because it shows fruits resistance to air flow during, drying process and storage process.

\subsection{Color measurement}

Color results are presented in table 4 . No significant variation was unregistered for Fruits color properties $\left(a^{*}, b^{*}, C^{*}\right.$ and $\left.H^{*}\right)$ except luminosity $L^{*}$ that values varied from 36.99 for Laabidate $(\mathrm{Lb})$ to 44.18 for Hamam Tahtani $(\mathrm{Ht})$.Light colored dates are considered better mentioned. 'Aziza Bouzid' from Hamam Tahtani plot showed a better color with higher values unlike Laabidate plot which is the lowest one. [9] Indicate that climatic condition is responsible for color variability as temperature, light and humidity. Cultural factors as thinning, grading, and Bunching can also affect color. 
Table 4. Color results of 'Aziza Bouzid' samples

\begin{tabular}{|c|c|c|c|c|c|}
\hline & $\mathbf{L}^{*}$ & $a^{*}$ & $\mathbf{b}^{*}$ & $\mathbf{c}^{*}$ & $\mathbf{h}^{*}$ \\
\hline Arj & $43.16 \pm 2.75^{\mathrm{cd}}$ & $5.80 \pm 1.83^{\mathrm{a}}$ & $28.82 \pm 4.58^{\mathrm{abcd}}$ & $29.40 \pm 4.11^{\mathrm{abc}}$ & $78.62 \pm 5.35^{\mathrm{c}}$ \\
\hline Cop.A & $42.10 \pm 1.43^{\mathrm{bcd}}$ & $9.86 \pm 1.93^{\mathrm{c}}$ & $27.34 \pm 2.27^{\mathrm{abcd}}$ & $29.06 \pm 2.78^{\mathrm{abc}}$ & $70.17 \pm 2.08^{\text {ab }}$ \\
\hline Zng.1 & $39.08 \pm 4.37^{\mathrm{ab}}$ & $5.91 \pm 0.67^{\mathrm{ab}}$ & $22.82 \pm 3.11^{\mathrm{abc}}$ & $23.57 \pm 2.78^{\mathrm{ab}}$ & $75.48 \pm 7.05^{\mathrm{bc}}$ \\
\hline Zng.2 & $44,37 \pm 2.56^{\mathrm{de}}$ & $6,37 \pm 0.23^{\mathrm{ab}}$ & $30,11 \pm 3.57^{\mathrm{cd}}$ & $30,78 \pm 4.12^{\mathrm{bc}}$ & $78,05 \pm 2.85^{\mathrm{ab}}$ \\
\hline Zng.3 & $40.38 \pm 0.91^{\mathrm{abc}}$ & $9.08 \pm 0.92^{\mathrm{bc}}$ & $21.85 \pm 2.49^{\mathrm{ab}}$ & $23.66 \pm 2.65^{\text {ab }}$ & $67.45 \pm 0.27^{\mathrm{c}}$ \\
\hline Zng.4 & $40.68 \pm 0.26^{\mathrm{bcd}}$ & $7.72 \pm 0.41^{\mathrm{abc}}$ & $26.18 \pm 0.98^{\mathrm{d}}$ & $27.29 \pm 1.07^{\mathrm{abc}}$ & $73.57 \pm 1.41^{\mathrm{abc}}$ \\
\hline $\mathrm{Ht}$ & $44.18 \pm 0.18^{\mathrm{a}}$ & $7.77 \pm 1.36^{\mathrm{ab}}$ & $29.77 \pm 0.37^{\mathrm{a}}$ & $30.76 \pm 1.40^{\mathrm{a}}$ & $75.38 \pm 2.61^{\mathrm{bc}}$ \\
\hline $\mathrm{Lb}$ & $36.99 \pm 0.61^{\text {de }}$ & $5.90 \pm 0.10^{\text {abc }}$ & $21.12 \pm 0.73^{\mathrm{bcd}}$ & $21.92 \pm 0.73^{\mathrm{bc}}$ & $74.40 \pm 0.75^{\text {bc }}$ \\
\hline OM.1 & $43.12 \pm 0.29^{\text {cd }}$ & $7.94 \pm 0.25^{\text {abc }}$ & $28.39 \pm 0.83^{\mathrm{abcd}}$ & $29.48 \pm 0.87^{\mathrm{abc}}$ & $74.37 \pm 0.03^{\mathrm{bc}}$ \\
\hline OM.2 & $49.07 \pm 1.51^{\mathrm{f}}$ & $8.33 \pm 0.58^{\mathrm{abc}}$ & $31.70 \pm 5.39^{\mathrm{abcd}}$ & $32.77 \pm 5.42^{\mathrm{c}}$ & $75.27 \pm 1.45^{\mathrm{bc}}$ \\
\hline Os & $41.39 \pm 0.22^{\mathrm{bcd}}$ & $6.05 \pm 0.35^{\mathrm{ab}}$ & $26.79 \pm 0.04^{\mathrm{abcd}}$ & $27.46 \pm 0.35^{\mathrm{abc}}$ & $77.27 \pm 0.73^{\mathrm{c}}$ \\
\hline $\mathrm{Lg}$ & $47.33 \pm 1.06^{\mathrm{ef}}$ & $6.84 \pm 0.28^{\mathrm{abc}}$ & $32.77 \pm 1.53^{\mathrm{abcd}}$ & $33.48 \pm 1.56^{\mathrm{abc}}$ & $78.21 \pm 2.18^{\mathrm{c}}$ \\
\hline
\end{tabular}

Values are average $(\mathrm{n}=100) \pm$ standard deviation. Different litters (a-e) show significant differences in the same row

$\mathrm{L}^{*}$ : lightness, $\mathrm{a}^{*}$ : red and green ratio, $\mathrm{b}^{*}$ : ratio yellow and blue, $\mathrm{C}^{*}$ : chroma, $\mathrm{H}^{*}$ : Hue

\subsection{Principal Component Analysis of physical quality characteristics of 'Aziza Bouzid' cultivar.}

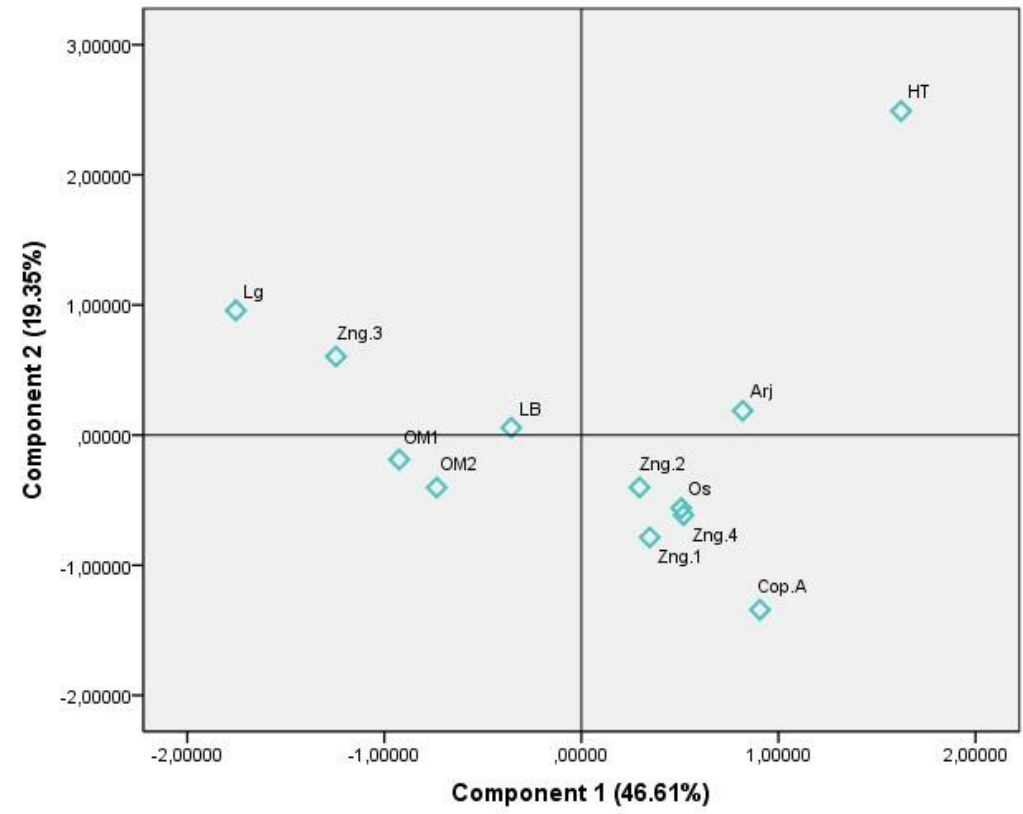

Fig. 2. Projection of the variables of the twenty studied dates fruits in the plane defined by two principal components; Arj:Aarja; Cop.A: Cooperative Aziza; Zng.1:Znaga 1; Zng.2:Znaga 2 , Zng.3 :Znaga 3;Zng.4 :Znaga4 ; Ht :Hamam Tahtani; Lb: Laabidate ;OM.1: Oulad lmaiz 1; OM.2:Oulad lmaiz 2; Os:Oulad Slimane; Lg :Loudaghir 
Table 5. Two main components explaining more than $65 \%$ of the total information on the physical and colorimetric traits of 'Aziza Bouzid' dates

\begin{tabular}{|l|c|c|l|l|c|}
\hline \multirow{2}{*}{ Variables } & \multicolumn{2}{|l|}{ Principal Component } & \multirow{2}{*}{ Variables } & \multicolumn{2}{l|}{ Principal Component } \\
\cline { 2 - 3 } \cline { 5 - 6 } & $\mathbf{1}$ & $\mathbf{2}$ & & $\mathbf{1}$ & $\mathbf{2}$ \\
\hline Width Fruit & 0.924 & 0.242 & AMD & 0.812 & 0.271 \\
\hline Pulp Weight & 0.900 & 0.365 & Length date & 0.696 & 0.331 \\
\hline GMD & 0.899 & 0.359 & thickness & 0.586 & 0.207 \\
\hline Ratio Pulp/Date & 0.899 & -0.343 & Weight Seed & 0.095 & 0.941 \\
\hline Ratio Seed/Date & -0.891 & 0.353 & Width Seed & 0.236 & 0.903 \\
\hline Surface & 0.878 & 0.341 & True density & 0.448 & 0.785 \\
\hline Weight Date & 0.860 & 0.452 & & & \\
\hline
\end{tabular}

Principal component analysis (PCA) was conducted to classify and determine the relationship between date samples and pre-harvest practices. Fig 2 and table 5 sum-up the results of PCA between 12 date samples. Two principal components were extracted from statistical analysis, which explained $65.96 \%$ of the total variance in the data set. The first and second PCs (PC1 and PC2) accounted for $46.613 \%$ and $19.943 \%$ of the variation; respectively. Factorial map showed discrimination between the studied dates samples and also has approved the interpretations mentioned above in a very simplified way. Compared to PC1, the studied 'Aziza Bouzid' samples could be divided into two groups. The first consists of 'Aziza Bouzid' samples from Hamam Tahtani (Ht), Cooperative Aziza (Cop.A), Aarja (Arj) Oulad slimane (Os) and Znaga (Zng.2, Zng.4) plots. The second was composed of dates from loudaghir 'Lg', Oulad lmaiz 1 (OM.1), Oulad lmaiz 2 (OM.2) et Znaga 3 (Zng.3). Actually, the first group is correlated with Pulp weight, dates, weight, Geometric mean diameter, width of dates, Surface, Aritmetique mean diameter, dates length, Bulk density, true density, Ratio $\mathrm{P} / \mathrm{D}$ and thickness. The second group is the opposite of the first one with respect to PC1. For principal component 2, the most distinct variables, were Aspect ratio R and Sphericity. According to the PC1, the effect of Pre-harvest practices is mainly manifested. In fact, Morphological 'Aziza Bouzid' samples from plot using good practices were opposed to those using traditional practices. 'Aziza Bouzid' sampled in Hamam Tahtani (Ht), Cooperative Aziza (Cop.A), Aarja (Arj) characterized by high morphological quality (high weight, high length and width dates, hand low seed percentage).

In opposition, samples collected from Loudaghir $(\mathrm{Lg})$, present a low quality with low size and high portion of seed. In addition, the results of this statistical analysis allow us to highlight a clear variability between studied 'Aziza Bouzid' dates samples according to morphological quality characteristics. PCA analysis exposed clearly the effects of the preharvest practices on dates quality.

\section{Conclusion}

This study revealed the effect of pre-harvest factors on the physical and colorimetric characteristics of the cultivar 'Aziza Bouzid. The interaction between physical quality and pre-harvest practices showed that the highest physical quality was recorded in the plots for which farmers' adapted adequate pre-harvest practices. However, a low quality of the cultivar 'Aziza Bouzid' was observed especially in the plots where ancestral practices are still used.

The obtained results can be exploited for the raise yield of dates and also for the improvement of Moroccan dates quality. Firstly the study raised adequate pre-harvest 
practices responsible for good dates quality (high weight and size of dates ) secondly it presented very important values of the physical parameters ( Sphericity, surface area, bulk, and true density), these results will be used for the design of harvesting, handling, processing and storing equipment that will keep the high quality of produced dates.

\section{References}

1. C.C.T. Chao, R.R Krueger, HortScience 42, 1077- 1082 (2007)

2. A. Amanat, M. Waly, M.M. Essa, D. Sankar. Dates: Production, Processing, Food, and Medicinal Values (2012)

3. S.H. Larbi. Les zones phoenicicoles marocaines', in: Dollé V. (ed.), Toutain G. (ed.). Les systèmes agricoles oasiens. Montpellier: CIHEAM 12 (1990)

4. M. Haddouch. Situation actuelle et perspectives de développement du palmier dattier au Maroc Importance du secteur phoenicicole Importance socio-économique oasis', In : Ferry M. (ed.), Greiner D. (ed.). Le palmier dattier dans l'agriculture d'oasis des pays méditerranéens. Zaragoza : CIHEAM (1993)

5. FAOSTAT Agro-statistics, Database, Rome: Food \& Agri. Organiz, United Nations (2017)

6. A. Hasnaoui, M.A. Elhoumaizi, M. Sindic, J. Sci. Res 3 ,139-149 (2010)

7. H.A. Chapron, M. Rahmani, A. Benmokhtar, R. Bouabid, Etude du positionnement commercial des variétés de dattes marocaines. Ministère de l'Agriculture et de la Pêche Maritime, O.R.M.V.A Ouarzazate. Maroc (2014)

8. M.D. Ramjan, M.T. Ansari, J. Med. Plant. Res 6, 16-18 (2018)

9. M. Arshad, M. Shahnawaz ,S. Shahkeela ,H. Maqsood, A. Mukhtar ,K.S. Sher, Euro, J. Exp. Bio 4, 82-89 (2014)

10. D. Bekele, J Plant Sci Res 5, 1-5 (2018)

11. V.G. Suchita, R. W. Vaishali, N.P. Bhagyashree, P.M. Nimkar, J. Appl. Hortic 17, 225-229 (2015)

12. N.N. Desai, V.M. Modi, G.K. Saxena, R.H. Chaudhari, M.K. Jaipal, K.H. Gohil, A. Gora, Int J Curr Microbiol Appl Sci 8, 1243-1249 (2019)

13. M.K Mahawar, K. Jalgaonkar, M. Kumar, V.S. Meena, B. Bhushan, ActaAgroph 24, 271 277(2017)

14. M.K. Jahromi, S. S. Mohtasebi, A. Jafari, R. Mirasheh, S. Rafiee , J. Agric. Sci. Technol 2, $1-9(2008)$

15 A. R. Moustafa, N. Abdel-Hamid, A. Abd El-Hamid, M. R. El-Sonbaty and S. K. M. Abd El-Naby Bull Natl Res Cent 43, 204 (2019).

16 R.A.A .Mostafa,A.M. El-Salhy, A.A. El-Banna and Y.M. Diab Middle East J. Agric. Res, 3, 517-521, 2014

17 H. Darouich, M.R. Cameira, J.M. Gonçalves, P. Paredes, L.S. Pereira, MDPI Water 9, 1-19 (2017)

18. O. Kabas, A. Ozmerzi, I. Akinci, J. Food Eng 73, 198-202 (2006)

19. N.N. Mohsenin, Physical properties of plant and animal materials: Physical Characteristics and Mechanical Properties, New York: Gordon and Breach Science Publisher (1978).

20. W .Burubai, A.B. Burubai, J Food Process Technol 6, 1-5. (2014)

21. C. Ozarslan, Biosyst. Eng, 83, 169-174 (2002)

22. S. Balasubramanian, R. Viswanathan, J Food Sci Technol 47, 279-284 (2014)

23.W. Herchi, H. Kallel, S. Boukhchina, Food Sci. Technol, Campinas 34, 464-470( 2014)

24. N.S. Al-Khalifah, E. Askari, A.E. Shanavas Khan, Emir. J. Food Agric 24, 456-461 (2012)

25. R. W. K. Qadri, S. Waheed, M. S. Haider, I. Khan, S. A. Naqvi, M. Bashir, M. M. Khanthe, J. Anim.Plant. Sci 26, 1268-1277 (2016)

26. M.K. Jahromi, S. Rafiee, A. Jafari, M.R. Ghasemi , R. Mirasheh , S.S. Mohtasebi, Int. Agrophysics 22, 221-224 (2008)

27. M. Haddou, S. Babahani, A. Idder, RBRS 6, 46- 55 (2016) 